\title{
Peruvian Botanical Biopesticides for Sustainable Development and Protection of the Environment
}

\section{Biopesticidas botánicos de origen peruano para el desarrollo sostenible y la protección del ambiente}

\author{
Bracho-Pérez, J. ( ${ }^{1}$ ); Tacza-Valverde, I. ( $\left.{ }^{1}\right)$; Vásquez-Castro, J. ( $\left.{ }^{2}\right)^{*}$ \\ *Corresponding author: jaque@lamolina.edu.pe
}

\begin{abstract}
Daphnia magna is proposed as a bioindicator to establish the minimum concentration capable of controlling pests before performing toxicity tests. This study uses the proposed pest control extracts of two Peruvian species, Clibadium peruvianum Poepp. (seeds) and Petiveria alliacea L. (leaves). The toxicological effects of the plant extracts were evaluated with D. magna, using five neonates over a period of 24-48 h. A lack of mobility or the absence of heart rhythm for $15 \mathrm{~s}$ under a stereomicroscope was considered to indicate mortality. Organic extracts were discarded due to their higher toxicity when compared with the aqueous extracts of $C$. peruvianum and $P$. alliacea, which had $\mathrm{LC}_{50}=460.74$ $\mathrm{mg} / \mathrm{L}$ and $\mathrm{LC}_{50}=711.18 \mathrm{mg} \mathrm{L}^{-1}$ at a concentration of $10 \mathrm{mg} \mathrm{L}^{-1}$, respectively. Using this Daphnia-safe concentration, toxicity tests were performed on the third instar larvae of Musca domestica (housefly). Higher activity was observed with an aqueous extract of seeds of $C$. peruvianum and a leaf aqueous extract of $P$. alliacea, showing $58.33 \%$ and $56.7 \%$ mortality against $M$. domestica, respectively. Both extracts induced abnormal changes in the development of the housefly, causing deformation, burns, and dehydration of tissues in the larvae. It is evident that using D. magna as a preliminary toxicological test allows the determination of concentrations that are safer to use while maintaining the activity of the extracts as a botanical biopesticide, thus posing the lowest risk to the environment, ecosystems, their species, and human health.
\end{abstract}

Key words: Botanical biopesticides, Clibadium peruvianum, Daphnia magna, housefly, Musca domestica, Petiveria alliacea.

\section{Resumen}

Se propuso el uso de Daphnia magna como bioindicador para establecer la concentración mínima capaz de controlar las plagas antes de realizar pruebas de toxicidad. Este estudio consistió en el uso de dos especies peruanas, Clibadium peruvianum Poepp (semillas) y Petiveria alliacea L. (hojas). Los efectos toxicológicos de los extractos de plantas se evaluaron con D. magna, utilizando cinco neonatos en un período de $24-48 \mathrm{~h}$. La falta de movilidad o ausencia de ritmo cardíaco durante $15 \mathrm{~s}$ bajo microscopio estereoscópico se utilizó como un indicador de mortalidad. Los extractos orgánicos se descartaron debido a su mayor toxicidad en comparación con los extractos acuosos de C. peruvianum y P. alliacea, que tenían $\mathrm{CL}_{50}=460.74 \mathrm{mg} \mathrm{L}^{-1}$ y $\mathrm{CL}_{50}=711.18 \mathrm{mg} \mathrm{L}^{-1}$ a $10 \mathrm{mg} \mathrm{L}^{-1}$ de concentración, respectivamente. Usando esta concentración segura, se realizaron pruebas de toxicidad en larvas de Musca domestica de tercer estadio. Se observó una mayor actividad con extracto acuoso de semilla de $C$. peruvianum $58,33 \%$ y extracto acuoso de hoja de $P$. alliacea $56,7 \%$ de mortalidad contra $M$. domestica. Ambos extractos indujeron cambios anormales en el desarrollo de la mosca común, causando deformación, quemaduras y deshidratación de los tejidos de las larvas. Es evidente que el uso de D. magna como prueba toxicológica preliminar permite el uso de concentraciones más seguras, manteniendo la actividad de los extractos como un bioplaguicida botánico y presentando el menor riesgo para el medio ambiente, los ecosistemas, sus especies y la atención de la salud humana.

Palabras clave: Bioplaguicida botánico, Clibadium peruvianum, Daphnia magna, mosca común, Musca domestica, Petiveria alliacea.

\section{Introduction}

One of the organisms most used in toxicological studies with pesticides is the crustacean Daphnia magna Straus (Cladocera: Daphniidae). Because D. magna is easy to rear in the laboratory, and has advantages such as short life cycle and high susceptibility to pesticides and other environmental pollutants, it has become a worldwide reference species for this type of study (Mansour et al., 2015; Qi et al., 2018).

\footnotetext{
${ }^{1}$ Universidad Nacional Tecnológica de Lima Sur. Facultad de Ingeniería y Gestión. Campus - Sector 3 Grupo 1A 03 - Cercado (Av. Central y Av. Bolívar) - Villa El Salvador, Lima 42, Perú

${ }^{2}$ Universidad Nacional Agraria La Molina (UNALM), Departamento de Entomología, Facultad de Agronomía, Av. La Molina s/n, Lima 12, Perú
} 
The housefly, Musca domestica L. (Diptera: Muscidae), is considered a vector of viruses, bacteria, and protozoa that cause many diseases in humans and other mammals and has become an important public health concern (Urzúa et al., 2010a; Sripongpun, 2008). Management of $M$. domestica has been carried out through the application and extensive use of synthetic insecticides, which in turn have caused serious environmental problems, such as the development of pest resistance, ecological damage, and irreversible damage to human health (Vásquez, de Baptista, Trevizan, \& Gadanha, 2008; Ahmed, Zain, \& Irfanullah, 2004; Nivsarkar, Cherian, \& Padh, 2001; Kristensen \& Jespersen, 2003; Taşkin, Kence, \& Göçmen, 2004; Khalaf, Hussein, \& Shoukry, 2009).

A vast number of studies conducted worldwide have focused on the insect-control uses of insect growth regulators (IGRs) and plant secondary metabolites (Céspedes, Salazar, Martínez, \& Aranda, 2005; Torres et al., 2003; Magalhães et al., 2010; Pohlit, Rezende, Lopes, Lopes, \& Neto, 2011; Urzúa et al., 2010b). Plant-derived compounds that are rich sources of bioactive chemicals provide promising alternatives to the current use of chemical pesticides for insect control (Khalaf et al., 2009). The Asteraceae family constitutes an important source of secondary metabolites, such as monoterpenes, sesquiterpenes, sesquiterpene lactones, diterpenes, triterpenes, flavonoids, coumarins, polyacetylenes, and benzofurans (Raal et al., 2011; Alvarenga, Ferreira, Emerenciano \& Cabrol-Bass, 2001; Ferreira, Brant, Alvarenga, \& Emerenciano, 2005).

The Asteraceae family is widely distributed in Perú, where there are almost 250 genera and 1590 species (Beltrán et al., 2006). One species of this family, Clibadium peruvianum Poepp. ex DC. (Asterales: Asteraceae), is known as "huaca" in the rainforest of Perú. Rainforest natives have long used leaves from $C$. peruvianum as a fishing aid (Arriagada, 1995; Arriagada, 2003; Pérez, Muñoz, Noyola, \& García, 2006; Bohm \& Stuessy, 1981; Bohm \& Stuessy, 1985; Czerson, Bohlmann, Stuessy, \& Fischer, 1979). The use of piscicidal extracts in fishing is considered favorable because these extracts are not persistent chemicals. Furthermore, they may represent a good pest control alternative that avoids the use of synthetic and non-biodegradable products. For instance, rotenone is a piscicide that is also currently used as a botanical control in agriculture (Harada, 1996; Gabriel \& Okey, 2009).

Petiveria alliacea L. (Phytolaccaceae) is a perennial herbaceous plant native to the Amazon rainforest and widely distributed in other areas, including tropical and Central America, Africa, Sri Lanka, and the southeastern United States. It is known as "mucura." Preparations of this plant have been widely used in the traditional medicine of South and Central America to treat many disorders. Reports indicate that it has anti-inflammatory, antimicrobial, anticancer, and stimulant effects, among others. Most studies of this plant have focused on its roots and on medical-pharmacological applications (Kubec,
Kim, \& Musah, 2002; Williams, Rosner, Levy, \& Barton, 2007; Luz et al., 2016).

However, some studies have shown that this plant also possesses great potential in controlling pests and that it is not necessary to depredate (uproot or destroy the plants) it for this purpose, since an effective preparation does not require the use of the plant's roots. In this sense, several studies of leaf and stem extracts have demonstrated their ability to control pests, such as via acaricidal and insecticidal action against larvae and adults of the cattle tick Rhipicephalus (Boophilus) and whitefly (Bemisia tabaci Genn.), respectively (Rosado et al., 2010; Cruz, Gamboa, Borges, \& Ruiz, 2013).

This study aimed to evaluate the toxicological effects of hexane, ethanol, and aqueous extracts of $C$. peruvianum and $P$. alliacea on D. magna in order to determine the extract with the lowest mortality risk and then to carry out toxicity tests on the third instar larvae of $M$. domestica.

\section{Materials and Methods}

\section{Material}

Two Peruvian species, C. peruvianum Poepp. (seeds) and $P$. alliacea L. (leaves), were collected from both Tingo María City, Rupa-Rupa District, situated in the Huánuco department $\left(09^{\circ} 24^{\prime} \mathrm{S}, 75^{\circ} 58^{\prime} \mathrm{W}\right)$, and Castillo district, Leoncio Prado Province, located in the Huánuco department $\left(09^{\circ} 16^{\prime} \mathrm{S}, 7^{\circ} 00^{\prime} \mathrm{W}\right)$, in August 2016. The Weberbauer Herbarium, Universidad Nacional Agraria La Molina, then confirmed the identification of both plants when voucher specimens were deposited there.

The plants were dried in an oven at $40{ }^{\circ} \mathrm{C}$ for $48 \mathrm{~h}$ and pulverized, and then $10 \mathrm{~g}$ of each dried plant material part was extracted with ethanol, hexane, or distilled water using an ultrasound bath at $48{ }^{\circ} \mathrm{C}$ for $2 \mathrm{~h}$. The extracts were filtered, and the organic extracts were dried on a rotary evaporator under reduced pressure at $38^{\circ} \mathrm{C}$ and dissolved in propylene glycol and distilled water.

\section{Preparation of extracts}

Dry ground seeds $(3 \times 10 \mathrm{~g})$ and leaves $(3 \times 10 \mathrm{~g})$ were extracted with $100 \mathrm{~mL}$ of $96 \%$ ethanol, hexane, or distilled water by ultrasonication at $48^{\circ} \mathrm{C}$ for $2 \mathrm{~h}$ and then filtered. The organic extracts were dried on a rotary evaporator under reduced pressure at $38^{\circ} \mathrm{C}$ and dissolved in propylene glycol.

\section{Test organism}

Experiments were conducted with strains of D. magna. Cultures of $D$. magna were maintained at a temperature of $20^{\circ} \mathrm{C} \pm 2{ }^{\circ} \mathrm{C}$ in water at $\mathrm{pH} 7.14$, with conductivity of $10 \mu \mathrm{S} \mathrm{cm}^{-1}$, alkalinity of $93.5 \mathrm{mg} \mathrm{CaCO}_{3} \mathrm{~L}^{-1}$, and total hardness of $45.6 \mathrm{mg} \mathrm{CaCO}_{3} \mathrm{~L}^{-1}$. The D. magna were fed 
with the algal species Pseudokirchneriella subcapitata according to ISO 6341 (2012), OECD 202 (2004), and USEPA 2021.0 (2002) methods.

\section{Acute ecotoxicity}

A reference test with sodium chloride $(\mathrm{NaCl})$ was also conducted to test the sensitivity of D. magna (24-h old). The static toxicity test was performed in plastic vessels containing $4 \mathrm{~mL}$ of test medium. For each concentration, five neonates were exposed to five test concentrations of dried extracts per liter from $1 \%\left(1000 \mathrm{mg} \mathrm{L}^{-1}\right)$ to $0.01 \mathrm{mg}$ $\mathrm{L}^{-1}\left(10 \mathrm{mg} \mathrm{L}^{-1}\right)$, without feeding during the test, for 24 and $48 \mathrm{~h}$. For each concentration, three replicates were used. Plastic vessels were incubated in darkness at $20^{\circ} \mathrm{C} \pm 2{ }^{\circ} \mathrm{C}$. The immobilization of treated organisms or the absence of heart rhythm for $15 \mathrm{~s}$ under a stereomicroscope was used to indicate mortality.

\section{Low environmental risk decision}

Taking into account the results obtained from the acute ecotoxicity test, the vegetable extracts and respective concentrations that exhibited toxicity against $D$. magna were discarded. The remaining extracts were used to carry out the control bioassays for the selected pest, $M$. domestica.

\section{Residual contact toxicity}

Bioassays were performed in order to demonstrate the insecticidal activity of each extract against $M$. domestica. For this purpose, each of the selected extracts from both plant types was mixed with an increasing amount of distilled water to obtain four solutions with dilutions ranging from $100 \%$ (undiluted) to $10 \%(100,80,50$, and 10). An aliquot of $1 \mathrm{~mL}$ of each extract was applied to each of four petri dishes. In each petri dish, the applied liquid was spread over the entire treatment area to form a thin film, which was evaporated under the Environmental Chemistry Laboratory conditions $\left(25^{\circ} \mathrm{C} \pm 2{ }^{\circ} \mathrm{C}\right.$ and $65 \% \pm$ $2 \%$ relative humidity $[\mathrm{RH}]$ ) for $10 \mathrm{~min}$. Once the treatment area was dry, 40 third instar larvae of $M$. domestica were placed in each petri dish, and the dishes were covered and sealed with Parafilm. The same process was performed with distilled water as a control. Four replicates per treatment were used in the experiment. For evaluation, the adults that emerged after 15 days were counted (Pérez, Bracho, \& Vásquez, 2012).

\section{Data analysis}

Taking into account the data related to acute ecotoxicity, the $\mathrm{LC}_{50}$ (concentration lethal to $50 \%$ of the population) was determined by applying the probit analysis as part of an appropriate statistical program (IBM SPSS Statistics $22)$. Student's $t$-test was used to examine the hypothesis of possible differences between the mean results from the two treatments. The efficacy of treatments (percentage of mortality at different concentrations) was evaluated through a one-way analysis of variance (ANOVA), with a significance level of $p=0.05$ after transformation of the data to square root of the arcsine to ensure a homogeneity of variances, using IBM SPSS Statistics (Zar, 1996).

\section{Results and Discussion}

\section{Acute ecotoxicity}

\section{Clibadium peruvianum Poepp. (huaca)}

The seeds of $C$. peruvianum were selected as the organ of interest for this plant, based on the study of Pérez et al. (2012), which demonstrated that the alcoholic extract of its seeds had higher insecticidal activity compared with the other organs of the plant.

Studies of ecotoxicity using D. magna have demonstrated that at $48 \mathrm{~h}$ of exposure, the lethal average concentration reached its highest value $\left(\mathrm{LC}_{50}=460.74\right.$ $\mathrm{mg} \mathrm{L}^{-1}$ ) for a concentration of $10 \mathrm{mg} \mathrm{L}^{-1}(0.01 \%)$, demonstrating that the aqueous extract of the seed possesses a minor toxic effect, unlike the more powerful effects of the alcoholic extracts $\left(\mathrm{LC}_{50}=164.36 \mathrm{mg} \mathrm{L}^{-1}\right)$ and hexanic extracts $\left(\mathrm{LC}_{50}=371.47 \mathrm{mg} \mathrm{L}^{-1}\right)$. As a result, the aqueous extract of the $C$. peruvianum became the only extract considered for further studies of biopesticide activity and development of future formulations for pest control (Table 1).

\section{Petiveria alliacea L. (mucura)}

The acute toxicity results of the extracts drawn from the leaves of the mucura plant demonstrated that the aqueous extract also exhibited the highest lethal concentration $\left(\mathrm{LC}_{50}\right.$ $=711.18 \mathrm{mg} \mathrm{L}^{-1}$ ) compared with those of the alcoholic extract $\left(\mathrm{LC}_{50}=255.50 \mathrm{mg} \mathrm{L}^{-1}\right)$ and hexanic extract $\left(\mathrm{LC}_{50}\right.$ $\left.=65.36 \mathrm{mg} \mathrm{L}^{-1}\right)$; the hexanic extract showed mortality in a concentration range of $10-100 \mathrm{mg} \mathrm{L}^{-1}$, equivalent to $0.1 \%$ $0.01 \%$ (Table 2).

The results obtained indicate that the aqueous extract of the $P$. alliacea has the lowest acute toxicity, even lower than the aqueous extract of $C$. peruvianum. However, both aqueous extracts must be considered since they both generate the lowest toxic effect to M. daphnia, which is the selected bioindicator.

This implies that the other extracts should no longer be considered in order to reduce future environmental toxicity risks, and $10 \mathrm{mg} \mathrm{L}^{-1}(0.01 \%)$ of dried extract per liter was the most appropriate concentration for the development of biopesticide activity studies.

\section{Insecticidal activity}

The results of the insecticidal activity reveal that both the aqueous extracts prepared caused mortality higher than $50 \%$, specifically, $58.33 \%$ for C. peruvianum (huaca) and 
Table 1. Toxic effect of Clibadium peruvianum Poepp. (huaca) extracts in terms of mortality of Daphnia magna during 24 and $48 \mathrm{~h}$ of exposure.

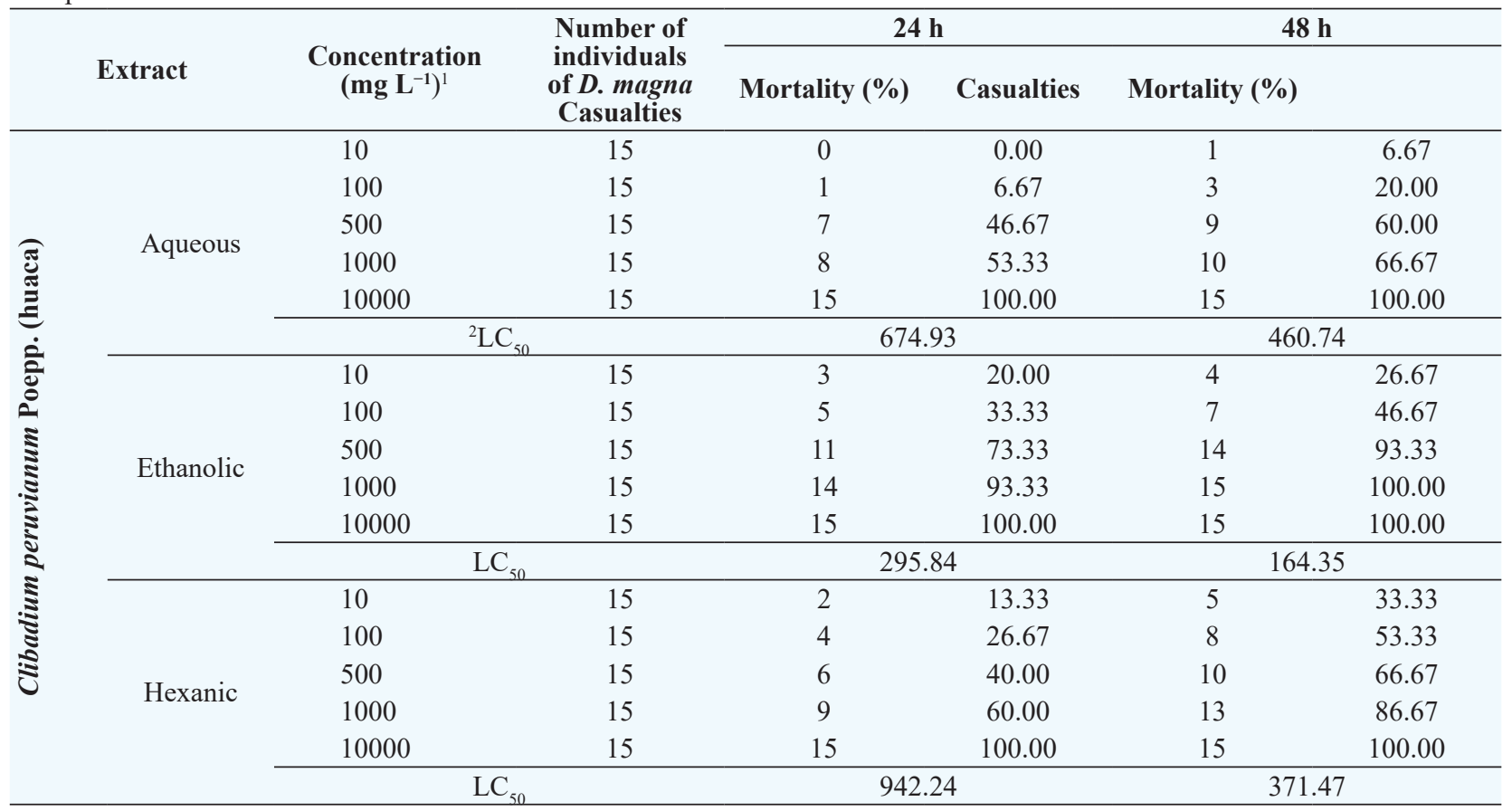

${ }^{1} \mathrm{mg} \mathrm{L}^{-1}=\mathrm{mg}$ of dry aqueous extract per liter, ${ }^{2} \mathrm{LC}_{50}$ is the concentration of $C$. peruvianum extracts that kill $50 \%$ of the test population of Daphnia magna within a designated period.

Table 2. Toxic effect of Petiveria alliacea L. (mucura) extracts in terms of mortality of Daphnia magna during 24 and $48 \mathrm{~h}$ of exposure.

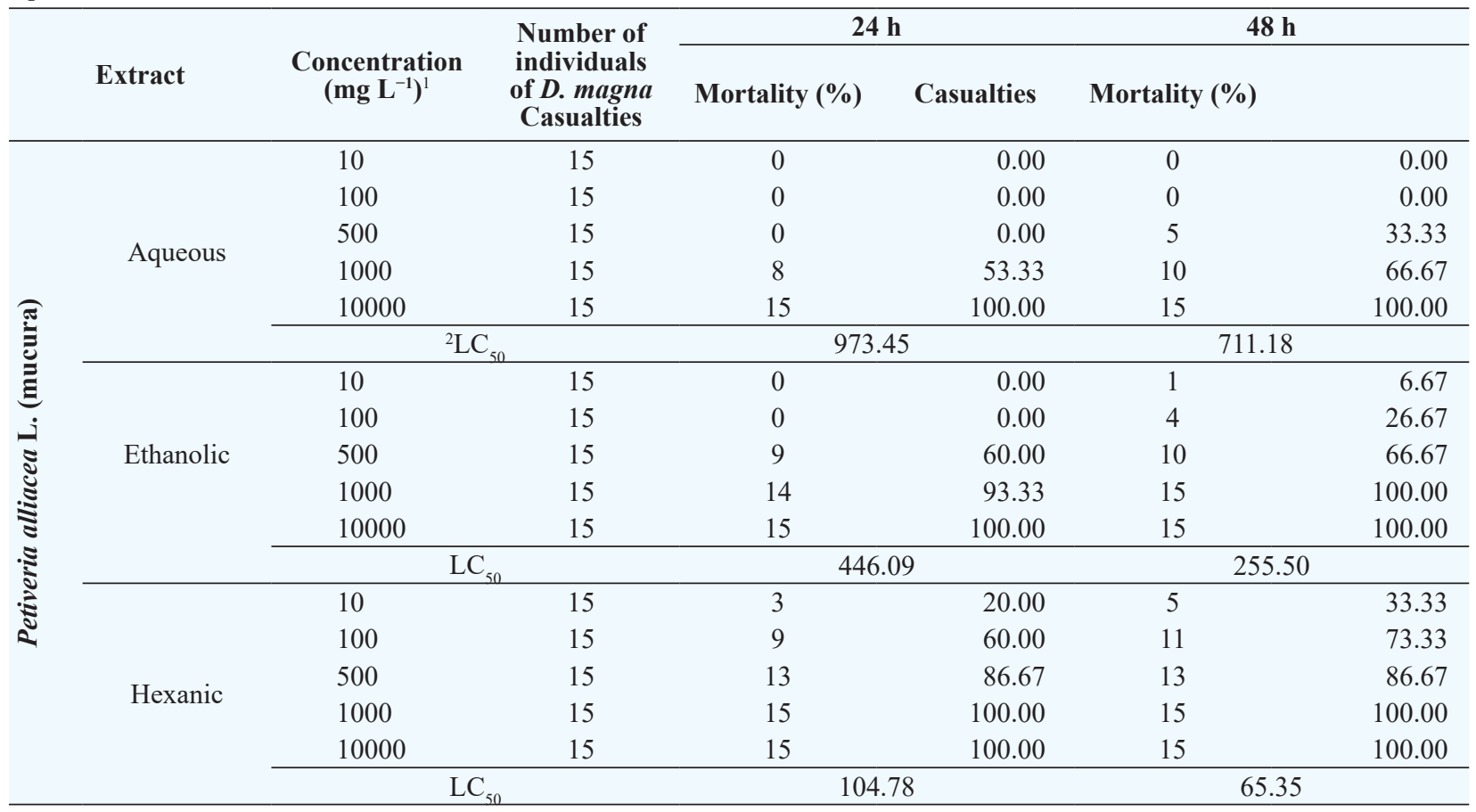

${ }^{1} \mathrm{mg} \mathrm{L}^{-1}=\mathrm{mg}$ of dry aqueous extract per liter, ${ }^{2} \mathrm{LC}_{50}$ is the concentration of P. alliacea extracts that kills $50 \%$ of the test population of Daphnia magna within a designated period.

$56.70 \%$ for $P$. alliacea (mucura). This indicates that huaca has a greater tendency to maintain a higher insecticidal effect (Table 3).

However, the means of observed mortality are not homogeneous. By applying Student's $t$-test, it can be determined that the hypothesis of the difference between the means of the two determinations is not confirmed. The level of significance $(p)$ of this test is lower than that of Levene's statistic, $F=0.05$, for huaca compared with mucura, obtaining $p=0.262$ and $p=0.167$, respectively. This means that the equality of the means was rejected. Therefore, the means obtained must be transformed by applying the square root of the arccosine and then by 
Table 3. Mortality percentages for the third instar larvae of Musca domestica exposed to aqueous extracts of $C$. peruvianum (huaca) and P. alliacea (mucura).

\begin{tabular}{ccc}
\hline \multirow{2}{*}{$\begin{array}{c}\text { Concentration } \\
\left(\mathbf{m g ~ L}^{-1}\right)\end{array}$} & \multicolumn{2}{c}{ Mortality (\%) } \\
\cline { 2 - 3 } & $\begin{array}{c}\text { C. peruvianum } \\
\text { extract }\end{array}$ & P. alliacea extract \\
\hline 10.00 & $58.33 \pm 0.10$ & $56.70 \pm 0.10$ \\
8.00 & $43.33 \pm 0.10$ & $35.00 \pm 0.10$ \\
6.00 & $20.00 \pm 0.10$ & $25.00 \pm 0.10$ \\
4.00 & $16.66 \pm 0.10$ & $11.00 \pm 0.10$ \\
2.00 & $10.00 \pm 0.10$ & $3.33 \pm 0.10$ \\
\hline
\end{tabular}

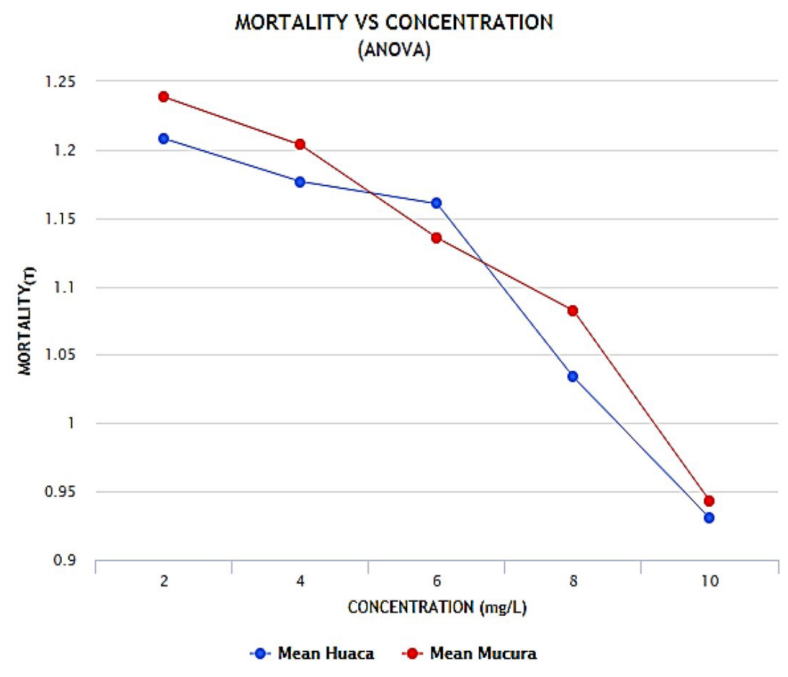

Figure 1. Mortality curve for Musca domestica larvae, where Mortality $_{(\mathrm{T})}$ indicates the percentage of mortality transformed according to Zar (1996), using the data presented in Table 3 versus concentration of $C$. peruvianum (huaca) and $P$. alliacea (mucura) extracts.

ANOVA, obtaining a graphical description of results in both toxicity studies on the housefly, as presented in Figure 1 (Zar, 1996).

Toxicity results allow the inference that although the extract of huaca leaves has, in general, greater toxicity, the behaviors of both extracts are similar, causing mortality higher than $50 \%$ to the third instar larvae of $M$. domestica at a concentration of $10 \mathrm{mg} \mathrm{L}^{-1}$ of dried extract. Both extracts induced abnormal changes in the development of the housefly, causing deformation, burns, and dehydration of tissues in the larvae, similar to the results of the study of Pérez et al. (2012).

The morphological aberrations obtained are similar to those described on Synthesiomyia nudiseta Wulp larvae (Khalaf et al., 2009; Khalil, Assae, Abo El Mahasen, \& Mahmoud, 2010) and on M. domestica (Elkattan, Ahmed, Elbermaway, \& Abdel-Gawad, 2011), causing a 24-h delay in the development of the larvae treated with an extract of seeds in comparison to other treatments. The effect of delay during the transformation from larvae to pupae was also described by other authors (Elkattan et al., 2011; Ande, 2001; Assar \& Abo-Shaeshae, 2004). This unusual extension of the larval growth period could be related to the effect of inhibiting the fly growth process by substances known as IGRs, a consideration that has been supported by other authors (Khalaf et al., 2009; Youssef, 1997; Wang, Li, \& Lei, 2005).

On the other hand, because the insecticidal activity considered in this study was found in extracts of the seeds and leaves, it is not necessary to kill the plants to obtain the needed raw material for these insecticides. The plants can continue to grow, thus preserving the species. It is very remarkable that the dilution chosen for the aqueous extract of $C$. peruvianum showed a pattern of biological activity similar to previous studies on this species, but at a much lower concentration. Both aqueous extracts caused deformations in the larvae, but to a lower extent. It is evident that using a bioindicator, such as D. magna, as part of the preliminary toxicological tests allows the choosing of the safest concentrations of a biopesticide while maintaining biological activity.

Finally, emphasis should be placed on the importance of continuing the chemical composition studies to establish the relationship between chemical composition and biological activity. This will enable the design of increasingly environment-friendly formulations of pest control, capable of protecting pest ecosystems, the species that inhabit them, and human health.

\section{Conclusions}

Daphnia magna can be used as a bioindicator to determine the minimum concentration capable of controlling pests before performing toxicity tests on pest species.

Toxicological evaluation with D. magna demonstrated that alcoholic and hexanic extracts of C. peruvianum and $P$. alliacea are more toxic to D. magna than the aqueous extract, evidencing the greater environmental impact of organic extracts.

The aqueous extracts of $C$. peruvianum and $P$. alliacea are environment-friendly, as measured by their relatively low toxicity to D. magna, and the appropriate extract that should be used for the control of $M$. domestica.

Finally, the toxicity tests carried out on Musca domestica demonstrated that both aqueous extracts of C. peruvianum and $P$. alliacea on $D$. magna have great potential for insect pest control.

\section{References}

Ahmed, S., Abdin, Z., \& Irfan, M. (2004). Evaluation of some pyrethroids for the control of house fly, Musca domestica L. International Journal of Agriculture and Biology, 6(5), 806-809.

Alvarenga, S. A., Ferreira, M. J., Emerenciano, V. P., \& 
Cabrol-Bass, D. (2001). Chemosystematic studies of natural compounds isolated from Asteraceae: characterization of tribes by principal component analysis. Chemometrics and Intelligent Laboratory Systems, 56, 27-37. https://doi.org/10.1016/S01697439(01)00103-4

Ande, A. T. (2001). Biological activities of some plant materials against the housefly-Musca domestica. Journal of the Nigerian Society for Experimental Biology, 1, 293-296.

Arriagada, J. (1995). Notes on Economics plants. Economic Botany, 49, 328-332.

Arriagada, J. (2003). Revision of the genus Clibadium (Asteraceae, Heliantheae). Brittonia, 55(3), 245 301. https://doi.org/10.1663/0007-196X(2003)055 [0245:ROTGCA]2.0.CO;2

Assar, A. A., \& Abo-Shaeshae, A. A. (2004). Effect of two insect growth regulators, methoxyfenozide and pyriproxyfen on the housefly, Musca domestica vicina (Diptera: Muscidae). Journal of the EgyptianGerman Society of Zoology, 44,19-42.

Beltrán, H., Granda, A., León, B., Sagastegui, A., Sánchez, I., \& Zapata, M. (2006). Asteraceae endémicas del Perú. Revista Peruana de Biología, 13(2), 64-164. https//doi.org: 10.15381/rpb.v13i2.1807.

Bohm, B. A., \& Stuessy, T. F. (1981). Flavonol derivatives of the genus Clibadium (Compositae). Phytochemistry, 20(5), 1053-1055. https://doi. org/10.1016/0031-9422(81)83025-7

Bohm, B. A., \& Stuessy, T. F. (1985). Further studies of flavonols of Clibadium (Compositae). Phytochemistry, 24(9), 2134-2136. https://doi. org/10.1016/S0031-9422(00)83144-1

Céspedes, C. L., Salazar, J. R., Martínez, M., \& Aranda, E. (2005). Insect growth regulatory effects of some extracts and sterols from Myrtillocactus geometrizans (Cactaceae) against Spodoptera frugiperda and Tenebrio molitor. Phytochemistry, 66(20), 2481-2493. https://doi.org/10.1016/j. phytochem.2005.07.010

Cruz, E. A., Gamboa, A. M., Borges, A. R., \& Ruiz, S. E. (2013). Insecticidal effect of plant extracts on immature whitefly Bemisia tabaci Genn. (Hemiptera: Aleyroideae). Electronic Journal of Biotechnology, 16(1), 1-9. DOI: 10.2225/vol16issue1-fulltext-6 Retrieved from http://www. ejbiotechnology.info/index.php/ejbiotechnology/ article/view/v16n1-6

Czerson, H., Bohlmann, F., Stuessy, F., \& Fischer, H. (1979). Sesquiterpenoid and acetylenic constituents of seven Clibadium species. Phytochemistry,
18(2), 257-260. https://doi.org/10.1016/00319422(79)80065-5

Elkattan, N. A., Ahmed, K. S., Elbermaway, S. M., \& Abdel-Gawad, R. M. (2011). Effect of some botanical materials on certain biological aspects of the housefly, Musca domestica L. The Egyptian Journal of Hospital Medicine. 42, 33-48.

Ferreira, M. J., Brant, A. J., Alvarenga, S. A., \& Emerenciano, V. P. (2005). Neural networks in chemosystematic studies of Asteraceae: A classification based on a dichotomic approach. Chemistry \& Biodiversity. 2, 633-644. https://doi. org/10.1002/cbdv.200590040

Gabriel, U., \& Okey, I. (2009). Effect of aqueous leaf extracts of Lepidagathis alopecuroides on the behaviours and mortality of hybrid Catfish (Heterobranchus bidorsalis X Clarias gariepinus) Fingerlings. Research Journal of Applied Science, Engineering and Technology, 1(3), 116-120.

Harada, J. (1992). Allelopathy and fish toxicity of aquatic weeds. International Symposium on Biological Control and Integrated Management of Paddy and Aquatic Weeds in Asia, 305. 19-25 October. Tsukuba, Japan.

ISO International Organization for Standardization. (2012). Water quality. Determination of the inhibition of the mobility of Daphnia magna Straus (Cladocera, Crustacea). Acute toxicity test (ISO 6341). Retrieved from https://www.iso.org/ standard/54614.html

Khalaf, A. A., Hussein, K. T., \& Shoukry, K. K. (2009). Biocidal activity of two botanical volatile oils against the larvae of Synthesiomyia nudiseta (Wulp) (Diptera: Muscidae). Egyptian Academic Journal of Biological Sciences, 2, 89-101.

Khalil, M. S., Assae, A. A., Abo El Mahasen, M. M., \& Mahmoud, S. H. (2010). Morphological effects of some insect growth regulators on Musca domestica (Diptera, Muscidae). Egyptian Academic Journal of Biological Sciences, 2, 29-36. https://doi. org/10.21608/EAJBSF.2010.17445

Kristensen, M., \& Jespersen, J. B. (2003). Larvicide resistance in Musca domestica (Diptera: Muscidae) population in Denmark and establishment of resistant laboratory strains. Journal of Economic Entomology, 96, 1300-1306. https://doi. org/10.1093/jee/96.4.1300

Kubec, R., Kim, S., \& Musah, R. A. (2002). S-Substituted cysteine derivatives and thiosulfinate formation in Petiveria alliacea-part II. Phytochemistry 61(6), 675-680. https://doi.org/10.1016/S00319422(02)00328-X 
Luz, D. A., Pinheiro, A. M., Silva, M. L., Monteiro, M. C., Prediger, R. D., Ferraz Maia, C. S., \& FontesJúnior, E. A. (2016). Ethnobotany, phytochemistry and neuropharmacological effects of Petiveria alliacea L. (Phytolaccaceae): A review. Journal of Ethnopharmacology. 185, 182-201. https://doi. org/10.1016/j.jep.2016.02.053

Magalhães, L. A., Lima, M., Marques, M. O., Facanali, R., Pinto, A. C., \& Tadei, W. P. (2010). Chemical composition and larvicidal activity against Aedes aegypti larvae of essential oils from four Guarea species. Molecules, 15, 5734-5741. https://doi. org/10.3390/molecules 15085734

Mansour, S. A., Abdel-Hamid, A. A., Ibrahim, A. W., Mahmoud, N. H., \& Moselhy, W. A. (2015). Toxicity of some pesticides, heavy metals and their mixtures to Vibrio fischeri bacteria and Daphnia magna: Comparative Study. Journal of Biology and Life Science, 6, 221-240. http://dx.doi.org/10.5296/ jbls.v6i2.8174

Nivsarkar, M., Cherian, B., \& Padh, H. (2001). Alphaterthienyl: A plant-derived new generation insecticide. Current Science, 81, 667-672.

OECD (2004). Test No. 202: Daphnia sp. Acute Immobilisation Test, OECD Guidelines for the Testing of Chemicals, Section 2, OECD Publishing, Paris. https://doi.org/10.1787/9789264069947-en

Pérez, G., Bracho, J. C., \& Vásquez, J. A. (2012). Efeito inseticida de Clibadium peruvianum sobre $\mathrm{Musca}$ domestica, e a sua composição química. XXIV Congresso Brasileiro de Entomología, 16. CuritibaParaná, 2012. Brasil.

Pérez, M. C., Muñoz, V. A., Noyola, A., \& García, F. (2006). Essential oil and phototoxic compounds in Clibadium surinamense L. and Montanoa grandiflora D.C. (Asteraceae). Phyton, International Journal of Experimental Botany, 75, $145-150$.

Pohlit, A. M., Rezende, A. R., Lopes, E. L., Lopes, N. P., \& Neto, V. F. (2011). Plant extracts, isolated phytochemicals, and plant-derived agents, which are lethal to arthropod vectors of Human tropical diseases: a review. Planta Medica, 77, 618-630. https://doi.org/10.1055/s-0030-1270949

Qi, S., Wang, D., Zhu, L., Teng, M., Wang, C., Xue, X., \& Wu, L. (2018). Neonicotinoid insecticides imidacloprid, guadipyr, and cycloxaprid induce acute oxidative stress in Daphnia magna. Ecotoxicology Environmental Safety, 148, 352358. https://doi.org/10.1016/j.ecoenv.2017.10.042

Raal, A., Kaur, H., Orav, A., Arak, E., Kailas, T., \& Muurisepp, M. (2011). Content and composition of essential oils in some Asteraceae species. Proceedings of the Estonian Academy of Sciences, $60,55-63$.

Rosado, A. J., Aguilar, C. A., Rodríguez, V. R., Borges, A. R., García, V. Z., \& Méndez, G. M. (2010). Acaricidal activity of extracts from Petiveria alliacea (Phytolaccaceae) against the cattle tick, Rhipicephalus (Boophilus) microplus (Acari: Ixodidae). Veterinary Parasitology, 168(3-4), 299303.

Sripongpun, G. (2008). Contact toxicity of the crude extract of Chinese star anise fruits to house fly larvae and their development. Songklanakarin Journal of Science and Technology, 30(5), 667672. Retrieved from http://rdo.psu.ac.th/sjst/journ al/30-5/0125-3395-30-5-667-672.pdf

Taşkin, V., Kence, M., \& Göçmen, B. (2004). Determination of malathion and diazinon resistance by sequencing the Md $\alpha \mathrm{E} 7$ gene from Guatemala, Colombia, Manhattan, and Thailand housefly (Musca domestica L.) Strains. Russian Journal of Genetics, 40, 377-380.

Torres, P., Ávila, J. G., Romo de Vivar, A., García, A. M., Marín, J. C., Aranda, E., Céspedes, C. L. (2003). Antioxidant and insect growth regulatory activities of stilbenes and extracts from Yucca periculosa. Phytochemistry, 64(2), 463-473. https://oi. org/10.1016/S0031-9422(03)00348-0

Urzúa, A., Santander, R., Echeverría, J., Cabezas, N., Palacios, S. M., \& Rossi, Y. (2010a). Insecticide properties of the essential oils from Haplopappus foliosus and Bahia ambrosoides against the housefly, Musca domestica L. Journal of the Chilean Chemical Society, 55, 392-395. http:// dx.doi.org/10.4067/S0717-97072010000300026

Urzúa, A., Santander, R., Echeverría, J., Villalobos, C., Palacios, S. M., \& Rossi, Y. (2010b). Insecticidal properties of Peumus boldus Mol. essential oil on the house fly, Musca domestica. Latin American and Caribbean Bulletin of Medicinal and Aromatic Plants, 9, 465-469.

USEPA. (2002). Method 2021.0: Daphnia pulex and D. magna Acute Toxicity Tests with Effluents and Receiving Waters in: Methods for measuring the acute toxicity of effluents and receiving waters to freshwater and marine organisms. Fifth ed., EPA Volume 821-R-02-012.

Vásquez, J. A., de Baptista, G. C., Trevizan, L. R., \& Gadanha, C. D. (2008). Fenitrothion and esfenvalerate stability during corn and wheat sample processing. Scientia Agricola, 65, 157-160. http:// dx.doi.org/10.1590/S0103-90162008000200008 
Williams, L. A., Rosner, H., Levy, H. G., \& Barton, E. N. (2007). A critical review of the therapeutic potential of dibenzyl trisulphide isolated from Petiveria alliacea L. (guinea hen weed, anamu). West Indian medical Journal, 56(1), 17-21.

Wang, J., Li, Y., \& Lei, CL. (2005). The repellency and fumigant activity of Artemisia vulgaris essential oil to Musca Domestica Vicina. Chinese Bulletin of Entomology, 42(1), 51-53.

Youssef, N. S. (1997). Toxic and synergistic properties of several volatile oils against larvae of the house fly, Musca domestica vicina maquart (Diptera: Muscidae). Journal of the Egyptian-German Society of Zoology, 22, 131-149.

Zar, J. H. 1996. Biostatistical analysis. Prentice-Hall. Inc. Upper Saddle River. New Jersey, USA. 